研究資料

\title{
近年の米国にみる体育教師の効果的フィードバックに関する研究の動向
}

\author{
深見英一郎
}

\section{The trend of research on physical education teachers' effective feedback in the U.S.A.}

\author{
Eiichiro Fukami
}

\begin{abstract}
The purpose of this study was to examine recent trends in research on physical education teachers' effective feedback, and to identify future research areas of interest. Several studies have indicated that frequent teachers' affirmative, corrective and specific feedback about students' motor learning has a significant positive relationship with increases in students' formative evaluation scores in physical education classes (e.g., Takahashi, Fukami, and others 1991-1997). Teacher feedback was also found to be a useful element for improving students' motor skills and performance. In recent years qualitative research on teaching methods in physical education has become accepted as a new research approach. However, with regards to teachers' feedback it is often difficult to discern whether qualitative research has been conducted, and in studies that do include qualitative aspects it is often left unclear what type of research was conducted and what the implications of the research results might be. In this study five recent books that deal with effective teaching of research on physical education were examined, and 31 suggestions concerning teachers' effective feedback were identified. We were particularly interested in the research methods and content of those dealing with experimental research, but found that this type of research was rather limited and that the content of actual physical education classes rarely played a part in the analysis. The vast majority of suggestions concerning feedback (23) presented in the examined studies were clearly the ideas and opinions of the researcher himself. In addition, we found that most experimental studies applied quantitative and qualitative methods simultaneously (5), while none of them relied exclusively on qualitative methods. These results lead us to conclude that it is necessary to examine the effectiveness of feedback based on a set of more meaningful indicators such as appropriateness and correctness of feedback in improving students' motor skills and performance as seen from the position of both teachers and students.
\end{abstract}

Key words : effective teaching, quantitative research, qualitative research (Japan J. Phys. Educ. Hlth. Sport Sci. 49: 583-593, November, 2004)

天理大学体育学部

厂 632-0071 奈良県天理市田井庄町 80

連絡先 深見英一郎
Tenri University, Faculty of Health, Budo and Sports Studies

80 Tainosho, Tenri-shi, Nara 632-0071

Corresponding author eiichiro@sta.tenri-u.ac.jp 
キーワード: 効果的指導, 量的研究, 質的研究

\section{I 研究の目的}

現在，世界的規模で学校体育の危機が叫ばれ， 国民へのアカウンタビリティに応える学校体育の あり方が議論されるとともに，優れた体育教師を 盖成するための教師教育のあり方に関心が向けら れている．2001年 1 月，文部科学省は「21 世紀 教育新生プラン一教育を変える 17 の提案一」を 示し，その中で，「教員の意欲や努力が報われ評 価される体制」をつくり，優秀な教師に対して人 事上の措置を講じたり表彰したりすることを提案 した，その一方で，効果的な授業等ができない教 師を他職種へ配置換えできる方途の搪大や免職の 措置ができるようになった。これらの取り組みは, これからの教育改革において教えるプロの教師を 育成しようとするねらいがある，体育教師にあて はめて考えれば，体育授業の中ですべての子ども に対して運動やスポーツに対する愛好的態度や適 切な社会的態度の育成，さらには健康への認識な どといった様々な能力を育成することが求められ ているのである。そのために，体育教師は子ども にただ運動を楽しませるだけでなく，単元過程で あるいは 1 時間の体育授業で確実に運動技能を習 得させることが1つの重要な課題となっている. 授業中，子どもは運動に取り組む過程でさまざま なつまずきや問題に行き当たる。そして，そのよ うなつまずきや問題が学習を哚める契機となり, 運動技能習得への意欲を生み出すカギになるとい われている（渡辺，1996）。しかし，もしそのよ うなつまずき状態が長く続いたり，放っておかれ たままで一向に運動技能の向上がみられなけれ ば，拉そらく子どもは練習が嫌になり途中で投げ 出してしまうだろう。子どもにつまずきがみられ たときには，その問題解決に向けて教師が積極的 に関わることが重要である。なかでも，次の運動 技能の改善につながる情報を伴ったフィードバッ クが大変有効であるといわれている.

体育授業中の教師のフィードバックにかかわっ て，これまで多くの関心が向けられ研究が行われ
てきた、たとえば，授業中子どもに対してどのよ うなフィードバックを営むべきかという研究成果 に着目して，先行研究を検討すれば，次のような 報告がみられる。1）個々の子どもに対して数多 くのフィードバックを与えること（Pieon， 1982 ; シーデントップ, 1988, pp. 246-247 ; 高 橋ほか，1991），2）運動した直後にフィードバッ クを与えること（Rink, 1993，p. 162 ; Metzler, 2000），3）運動学習にかかわって肯定的・矯正的 フィードバックを与えること（Sharpe，1993； Metzler，2000)，4）連動学習にかかわって具体 的フィードバックを与えること（Werner and Rink, 1989 ; Magill, 1993), 5）運動学習にか かわって表現豊かに与えること (Carlisle and Phillips, 1984 ; シーデントップ, 1988, pp. 148170 ; 高橋ほか，1996；深見ほか，1997）。

このように，教師の効果的フィードバックにか かわって，数多くの研究成果がみられる。これら の多くは，あらかじめ概念化された授業中の教師 行動や生徒行動の出現頻度を算出し, 授業成果得 点との関係から導き出された研究成果である。こ のような量的研究では, 体育授業のある側面を数 量的に理解できても，その行動が出現した意味や その関係性については理解できないといわれてい る（高橋・鈴木，1994）。このことは，教師のフ イードバック研究にかかわって，まだいくつかの 課題が残っていることを示している.

くわえて, 今日の体育授業研究では新たな研究 方法として質的研究が注目されている. 質的研究 とは，たとえば授業中のある1つの行動が，なぜ 出現したのか，またそれは全体状況の中でどのよ うな意味をもつのかを理解しようとする研究であ る (Bodgan and Biklen, 1992, pp. 29-33). Silverman and Skonie（1997）は，1980年から 1994 年に出版された米国の主要な学術研究誌 (例：JTPE誌，RQES誌ほか) を対象に，体育 の教授研究 (Research on Teaching in Physical Education）をレビューしている。全 179 の研究 論文が抽出・分析された結果，そのほとんどが量 的研究 $(162$ 研究：91\%) であり，質的研究はわ ずかに 16 研究 $(9 \%)$ であったと報告している. 
このように，近年の体育授業研究において質的研 究の割合は少なく, 教師のフィードバックに関わ ってどのような質的研究が行われているのか，未 だ確認されていない. しかし，質的研究は量的研 究の問題点を克服し，教師のフィードバック技術 の確立に向けて重要な示唆を与えてくれると考え られる。

以上のことから，本研究では，優れた体育教師 を養成するためのフィードバック技術の確立に向 けて，米国に打ける教師のフィードバック研究の 動向を明らかにすることを目的とした。近年にお ける教師の効果的フィードバックに関する量的・ 質的研究の動向を分析し，それらをふまえて今後 の検討課題を明らかにすることにした。

\section{II 研究の方法}

近年，米国で出版され，教師の効果的な指導方 法に関する知見を数多く取り扱った 5 冊の文献を 分析した注1)。 5 冊の文献は，次の通りである。

(1) Graham, G. (2001) Teaching children physical education: Becoming a master teacher 2nd ed. (2) Mawer, M. (1995) The effective teaching of physical education. (3) Rink, J. (1993) Teaching physical education for learning. (4)
Siedentop and Tunnehill (2000) Developing teaching skills in physical education 4 th ed. (5) Silverman and Ennis (1996) Student learning in physical education.

ここでは，1980年以降に著された教師の効果 的フィードバックに関する知見を収集した。それ は，1980年代に組織的観察法が開発され，授業 過程の教師行動や生徒行動の事実が客観的に分析 されるようになり，この時期を境に体育授業研究 が活発に行われるようになったといわれているか らである（高橋，1989）。これらの文献の中から， 教師の効果的フィードバックに関する知見をすべ て抽出した。また，それぞれの知見について，文 献リストに基づいて原本論文に立ち㞍り，1）フ イードバック研究の方法，2）フィードバック研 究の内容及び成果という 2 視点で教師の効果的フ イードバック研究の動向を検討した注2)。

研究方法の分析では, 抽出した教師の効果的フ イードバックに関する知見は，それぞれ実際の体 育授業を刘象として実証的に分析された研究成果 であるか，あるいは単に研究者の考え・意見であ るかを分類した。実証的研究をふまえた研究成果 については，さらにフィードバックに関する質的 研究の割合を明らかにするために，表1に基づい て研究方法の記述内容を検討した注3)。具体的に

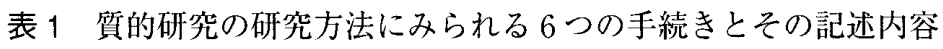

1. 参与者に関する記述

参与した教師，クラス，生徒に関する詳細な特徴

2. サンプリングに関する記述

目的的サンプリング，対象の選択基準，規準に基づく標本抽出

3. 研究への参与の承諾に関する記述

参与者に対する事前の研究内容の通知, 教師, 保護者, 学校長, 学校区の責任 者に対する研究参加への同意，インフォームドコンセント

4. データ収集に関する記述

フィールドノーツ, ジャーナル，フォーマルインタビュー，インフォーマル

インタビュー，ドキュメント

5. データ分析に関する記述

クロス一ケース分析, 帰納的分析法, 分析的帰納法, ケース分析，スケッチ ーパッド法, 比較法

6.データの信頼性及び妥当性に関する記述

トライアンギュレーション，メンバーチェック，長期的参与観察による行動 記録

（大友ほか，2002,pp. 97-99，表 1 質的体育授業研究論文の目的と方法）より

一部抜粋して筆者が作成 


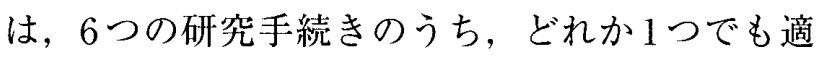
用・記述されている場合には「質的研究」と判断 した.また，研究内容及び研究成果の分析では, フィードバックを与える「教師」の視点とそれを 受け取る「子ども」の視点という2つに分けて分 析した.くわえて，それぞれの視点について，さ らに先行研究の検討から導かれた具体的な分析視 点で分類し，検討した。

\section{III 結果と考察}

5 冊の文献の中から, 教師の効果的フィードバ ックに関する知見を抽出した結果, 計 24 人の研 究者（グループ）による全 31 の知見が抽出され た。

\section{1. 研究方法の分析}

すべての知見の研究方法を分析した結果，表 2 に示したように実証的研究から得られた研究成果 は $8 \supset(26 \%)$ で，それ以外はすべて研究者の考 え・意見であることが示された。また，実証的研 究から得られた $8 つ の$ 研究成果について, 表 $1 に$ 照らして質的研究の有無を検討した結果，5つの 質的研究が確認された。それらの質的研究には, 次のような $3 つ の$ 質的研究方法が適用されてい た。

(1)事前にオリエンテーションが行われ，教師, 子ども, 学校長さらには保護者に対して, 研究プ ログラムの意図や進め方に関する説明が行われ， 同意が得られていた（=インフォームドコンセン ト) (Bonnie, 1997 ; Rikard, 1991, 1992 ; Silverman et al., 1993 ; Steven, 1996).

(2)授業中に与えられた運動課題や教師のフィー ドバックに対する教師と子どもの認識を理解する ために，毎時間授業終了後に彼らに対してインタ ビューが行われた(=フォーマルインタビュー注4) (Bonnie, 1997 ; Steven, 1996).

(3)被験者となる子どもの運動技能レベルの判定 は，運動技能テストを実施した上で，研究者，独 立した観察者（運動の専門家），担任教師という 3者の合意により決定された（=トライアンギュ
表 2 効果的フィードバックに関する研究の分析

\begin{tabular}{|c|c|c|c|c|}
\hline \multicolumn{2}{|c|}{ フィードバックの研究方法 } & \multicolumn{3}{|c|}{ 計 } \\
\hline \multirow{3}{*}{$\begin{array}{l}\text { 実証的 } \\
\text { 研究 }\end{array}$} & 量的研究 & $3(10)$ & & \multirow{4}{*}{$\begin{array}{c}31 \\
(100)\end{array}$} \\
\hline & 量的研究 + 質的研究 & $5(16)$ & $\begin{array}{c}8 \\
(26)\end{array}$ & \\
\hline & 質的研究 & $0(0)$ & & \\
\hline \multicolumn{2}{|c|}{ 研究者の考え・意見 } & \multicolumn{2}{|c|}{$23(74)$} & \\
\hline
\end{tabular}

※実数 (\%) (Silverman and Skonie, 1997, p. 303, Figure 1 Coding categories を参考に作成)

\section{レーション) (Rikard, 1991).}

これらの研究では，すべて組織的観察法を用い たフィードバックのカテゴリー分析や，運動技能 の成果を得点化するといった量的な研究方法が併 用されており，質的な研究方法のみを用いた質的

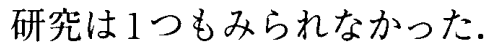

\section{2. 研究内容及び研究成果の分析}

フィードバックの研究内容を分析した結果, 表 3 に示したように「教師」に関しては，頻度 $(13 \%)$, テクニック $(22 \%)$, 言語内容 $(22 \%)$, 指導経験・運動知識レベル $(10 \%)$ という計 4 視 点（計 21）に分けられた。また，「子ども」に関 しては, 運動技能・知識レベル $(10 \%)$, 運動学 習量 $(13 \%)$, 学習状況 $(10 \%)$ という 3 視点 （計 10）に分けられた。教師に着目したフィード バック研究 $(67 \%)$ と比較して，子どもに着目 したフィードバック研究 $(33 \%)$ の割合は総じ て少ないことが示された。それは，クラスという 様々な子どもに対応して効果的フィードバックの あり方を明確にすることは非常に困難だからであ ると考えられる。

以下では, 研究内容及び研究成果の具体的中身 について考察していくことにする.

1）「教師」に着目したフィードバック研究

(1) フィードバックの頻度

一般に，体育授業中の教師のフィードバックは 少ないよりも数多く与える方が有効であり (Metzler, 2000, p. 106), 教師が具体的なフィ ードバックや子どもの運動に関する結果の知識を 提供すればするほど，学習はより促進される 
表 3 効果的フィードバックに関する研究の内容

\begin{tabular}{|c|c|c|c|c|}
\hline \multicolumn{2}{|c|}{ 研究内容の分析視点 } & \multicolumn{3}{|c|}{ 計 } \\
\hline \multirow{4}{*}{$\begin{array}{c}\text { 教師に } \\
\text { 着目した } \\
\text { 知見 }\end{array}$} & フィードバックの頻度 & $\begin{array}{c}4 \\
(13)\end{array}$ & \multirow{4}{*}{$\begin{array}{c}21 \\
(67)\end{array}$} & \multirow{7}{*}{$\begin{array}{c}31 \\
(100)\end{array}$} \\
\hline & $\begin{array}{l}\text { フィードバックの } \\
\text { テクニック }\end{array}$ & $\begin{array}{c}7 \\
(22)\end{array}$ & & \\
\hline & $\begin{array}{l}\text { フィードバックの } \\
\text { 言語内容 }\end{array}$ & $\begin{array}{c}7 \\
(22)\end{array}$ & & \\
\hline & $\begin{array}{l}\text { 教師の指導経験・ } \\
\text { 運動知識レベル }\end{array}$ & $\begin{array}{c}3 \\
(10)\end{array}$ & & \\
\hline \multirow{3}{*}{$\begin{array}{c}\text { 子どもに } \\
\text { 着目した } \\
\text { 知見 }\end{array}$} & $\begin{array}{l}\text { 子どもの運動技能・ } \\
\text { 知識レベル }\end{array}$ & $\begin{array}{c}3 \\
(10)\end{array}$ & \multirow{3}{*}{$\begin{array}{c}10 \\
(33)\end{array}$} & \\
\hline & 子どもの運動学習量 & $\begin{array}{c}4 \\
(13) \\
\end{array}$ & & \\
\hline & 子どもの学習状況 & $\begin{array}{c}3 \\
(10)\end{array}$ & & \\
\hline
\end{tabular}

※実数 (\%) (Silverman and Skonie, 1997, p. 303, Figure 1 Coding categories を参考に作成)

(Magill, 1994, pp. 317-318 ; Bonnie, 1997, p. 390）といわれている. しかし，一方で「いい よ」「OK」等のフィードバック（賞賛）は，与 えすぎると子どもは理想的なパフォーマンスとは どういうものかが理解できなくなる（Mawer, 1995，p. 188）。また，教師が子どもの良いとこ ろをほめたり，努力したことを認めたりせず，子 どものあら探しばかりして続けざまに指摘・修正 するようなフィードバック（『修正の複雑化 ('correction complex')』『間違い探し指導スタ イル ('fault-finder' style of teaching)』）は子ど もから有益に受けとめられず，絶対に与えてはな らない (Mawer, 1995, p. 194) といわれている.

これらのことから, 教師のフィードバックはそ の言語内容や対象となった子どもの学習状況によ って，数多く与えることが必ずしも望ましいとは いえず，状況に応じて適切な頻度があることが示 唆された。

(2) フィードバックのテクニック

(1)賞賛と助言を組み合わせて繰り返し与える 教師は子どもの運動技能改善に向けて最初のフ イードバックを与えた後, その子どものパフォー マンスを見届けず，放ったらかしにして別の子ど もの指導に移ってしまう傾向があるという。これ
では, 教師のフィードバック効果は半減してしま う。子どもが教師のフィードバックの意図を理解 して，実際につまずきを改善するまでに一定の時 間がかかるため，教師は子どもの傍にいて繰り返 しフィードバックを与える必要がある（Mawer, 1995, p. 194 ; Sharpe, 1993, p. 13).またその 結果，子どもにわずかでも運動技能の改善や向上 がみられたときには見逃さず賞賛するべきである (Silverman and Ennis, 1996, p. 188).

(2) 1 つの重要な動作の局面に焦点づけて与える 運動につまずいている子どもは，たいてい「自 分は今，どういう動作をしているのか」という情 報を処理する能力が低下している。したがって， 教師は子どもにとって意味のある情報を確実に伝 えるために，1回につき1つの動作局面 (critical component）に焦点づけてフィードバックを与え ることが重要である(『シンプルフィードバック』 (Graham, 2001, p. 140)).

(3)言語的フィードバックと非言語的フィードバ ックを組み合わせて与える

教師が言語的フイードバックを与える際に，お 手本となる運動を演示したり子どもの運動を補助 すれば，フィードバックの効果は向上する (Sharpe，1993，p. 13）といわれている. 特に， 運動のイメージが貧困な子どもには，身ぶり・手 ぶりを添えて説明したり，動作の過程を容易にイ メージさせる非言語的フィードバックは大変有効 である注5).このように，言語的フィードバック と非言語的フィードバックを組み合わせたコンビ ネーション型フィードバックは，言語的内容のみ を用いるよりも有効である（Metzler, 2000， p. 106）といわれている.

（3）フィードバックの言語内容

(1)子どもにとって有益な情報

子どもの不適切な動作を修正したり，それを修 正させるための具体的なフィードバック情報を提 供することが重要である（深見ほか，1997， pp. 175-177)。ここでは，そのようなフィードバ ック情報について具体的に言及された知見を示し た。たとえば，

a）子どもの不適切な動作を指導したり，それ 
表 4 教師の効果的な賞賛のしかた

1. 子どもの技能の伸びや, 優れた達成に対して賞賛す べきである（達成の質，信頼性，個性といったもの は達成した量以上により重要である）

2. 生徒が自分の達成に気付いていないときには，教師 は賞賛を与えて, 達成したことに気付かせるべきで ある

3. 賞賛した子どもからよい反応が返ってきたときに は，さらに賞賛すべきである

4. 子どもに対して何らかの情報を与えたり評価を行 うべきであり，それによって子どもを統制してはい けない（賞賛は，課題に焦点化すべきであり，教師 自身を満足させることに焦点化すべきではない)

5. 子どもが明確な目標を達成したことを条件に賞賛 すべきである

6. 明確に行わなければならない

7. 多様に行われるべきであるし，信頼性の高さを示す ものでなければならない

8. わざとらしく大げさに行なうのではなく, 自然に行 わなければならない

9. 大部分の賞賛は, プライベートに（非公式に）行う ベきである

10. 個別に行うべきである

11. 子どもの成功が, 子ども自身の努力と能力に起因す るものとして賞賛すべきである

12. 子どもの努力が, 子ども自身の内発的動機づけに起 因するものとして賞賛すべきである

(Silverman and Ennis, 1996, p. 188)

を修正させるための具体的なフィードバック情報 は有効である（Silverman et al., 1992, pp. 341343 ; Stroot and Oslin, 1993, p. 33).

b）子ども自身が運動体験から直接受けとるこ とができない情報や，学習キュー注6)を与えるよ うなフィードバック情報は有効である（Graham, 2001, p. 138 ; Metzler, 2000, pp. 101-102 ; Mawer, 1995, p. 187).

(2)明確な達成基準に基づく賞賛

Silverman and Ennis（1996，p. 188）は，表4 に示したように効果的な賞賛のしかたについて言 及している．その中で，「1. 子どもの技能の伸び や優れた達成に対して賞賛すべきである（達成の 質, 信頼性, 個性といったものは達成した量以上 に重要である)」「5，子どもが明確な目標を達成 したことを条件に賞賛すべきである」という項目 がみられる，これらのことから，教師の賞賛は単 に子どもの運動技能の達成・向上を承認し学習意 欲を高める（Van der Mars，1989, pp. 166-167) だけでなく達成目標を明確にして，それを習得さ
せる上で有益な情報となると考えられる。

(3)否定的フィードバックの有効性

これまで教師の否定的フィードバックは，子ど もの学習にマイナスに作用するため, 決して用い るべきではないという考え方が一般的であった。 しかし，近年そのような常識を覆すような研究結 果が報告されている，たとえば，子どもが学習に 集中できず自分の誤りを認識できない場合は，否 定的なフィードバックを与えることによって䛊り に気付かせる必要がある，それにより，子どもは 自分の誤りを認識して正しく修正することができ るのである（Mawer，1995，pp. 188-189； Graham, 2001, p. 141). また, 賞賛と批判をバ ランスよく合わせ持ったフィードバック情報は単 なる結果の知識以上の情報が含まれる（Mawer,

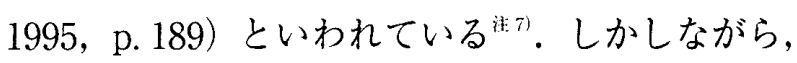
否定的な感情を伴った批判や，子どもの努力や運 動への挑戦を否定するような否定的フィードバッ クは，間違いなく子どもの学習にマイナスに作用 するため，絶対に避けるべきである（Mawer， 1995, p. 189).

（4）教師の指導経験・運動知識レベル

運動指導の経験が豊かな教師は, そうでない教 師と比較してフィードバックを与える際の認知構 造（perceptual map）が複雑であり，子どもの 様々な学習場面に応じて適切な状況判断ができる といわれている (Steven, 1996, p. 167).この ことから, 運動指導について豊かな経験と知識を 持つ教師は，子どもの運動のつまずきを見抜き， それを修正するための具体的なフィードバックを 数多く提供できると考えられる.その一方で, 運 動についてわずかな知識しか持っていない教師 は，運動のつまずきを見抜くことができず，もし 見抜くことができたとしても，その問題を解決す るための具体的フィードバックを与えることはで きない（Lee et al., 1993，p. 236）といわれてい る.

また，不適切なフィードバック情報は子どもの 学習を抑制する. そのような情報は, 教師の状況 判断ミスや間違った知識からもたらされることか ら，教師は運動技術（motor skills）に関して正 
しい知識を習得する必要がある（Mawer，1995， p. 185).

2）「子ども」に着目したフィードバック研究

（1）子どもの運動技能・知識レベル

初めての運動に取り組む子どもは，「早い」「遅 い」といった教師の単純なフィードバックを理解 するだけで精一杯であり（Magill and Wood, 1986, pp. 172-173), 正確で具体的なフィードバ ックは学習の初期段階を習得した子どもに限り有 効である（Mawer，1995，p. 188）といわれてい る。これは，教師がどんなに正確で具体的なフィ ードバックを与えたとしても，それを受け取る子 どもに，フィードバックの内容を理解する能力が 備わっていなければ，教師のフィードバックは徒 労に終わってしまうことを示している．教師のフ イードバックの有効性は，フィードバック情報を どれだけ理解できたかという子どもの認知レベル によって決定される（Silverman and Ennis， 1996, pp. 177-178）といわれている.

（2）子どもの運動学習量

Rikard（1991，p. 283）は，教師のフィードバ ックを受けとった子どもに成功裡な課題従事 (successful practice）がみられなかった原因は， フィードバックを受けとった後，子どもに十分な 練習時間が保障されなかったからであると指摘し ている．このことは，教師のフィードバック効果 を高める上で，子どもの十分な運動学習量が重要 であることを示している。しかし，単に十分な運 動学習量を確保するだけでは，フィードバックの 効果は期待できない，そこでは，子どもが質の高 い練習に対して，高い成功率で何度も取り組んで いるかどうかが重要であり（Silverman and Ennis, 1996, pp. 179-180)，そのことをきちん と評価する教師のフィードバックがさらに必要と なると考えられる注8).

（3）子どもの学習状況

運動学習に対して内発的に動機づけられていな い子どもにとって，教師の単純で一般的なフィー ドバックは有効である（Graham，2001，pp. 138139）。また，子どもが頻繁に失敗を繰り返してい れば，最初に教師は子どもを励ましてあげ，次に
つまずきを改善するためのフィードバックを与え ることが重要である（Sharpe, 1993, p. 13）。し かし一方で，子どもが次のような学習状況であれ ば，教師のフィードバックが子どもの学習に有効 に作用しない場合があるといわれている。たとえ ば，(1)子どもが運動から直接内在的フィードバッ クを受け取り，次にどうすればよいかについて十 分なイメージが持てた場合，さらに，(2)子どもが 教師のフィードバックに完全に依存してしまい, 運動に内在したフィードバックを用いることがで きない場合（Magill, 1994, pp. 318-320）であ る.

このように教師のフィードバックが常に子ども の学習に肯定的に作用するとはかぎらないため, 子どもの学習状況をふまえた上でフィードバック の有効性を検討していく必要がある.

\section{IV まと め}

本研究では，近年における教師の効果的フィー ドバックに関する研究動向を分析し，それをふま えて今後の検討課題を示唆しようとした。近年, 発刊された体育授業における教師の効果的な指導 方法に関する 5 冊の英語文献から，全 31 の効果 的フィードバックに関する知見をレビューし，そ れらの研究方法および研究内容を検討した。その 結果, 実証的分析から得られた研究成果は 8 つ $(26 \%)$ で, そのうち 5 つの研究では量的研究と 質的研究の両方が適用されていた。このことから， 教師の効果的フィードバックに関する知見の多く は,研究者の経験的見地からの考えや意見であり， 実証的分析に基づいた研究成果は少ないことが明 らかであった。また，質的研究の数はさらに少な く, 研究の準備段階において質的な研究手続きが 適用されていた程度であり，質的な研究方法のみ

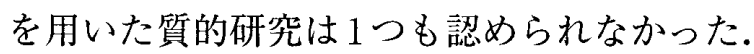

効果的フィードバックに関する研究内容を検討 した結果，教師の視点と比較して，子どもの視点 に着目したフィードバックの研究は少なかった。 本来，フィードバックの有効性は，教師がどのよ うなフィードバックを与えた場合に, 子どもの学 
表 5 子どもの学習反応に対応した教師のフィード バックのあり方

1. 生徒が正しく, 素早く, 自信をもって運動学習に 取り組んでいる場合には，手短かに生徒の取り組 みを肯定的に支援し，学習の勢いを妨げないこと

2. 生徒は正しく運動学習に取り組んでいるが, 自信 がなさそうにしている場合には手短かに生徒の取 り組みを肯定的に支援し，運動技術に関する具体 的な情報を与えること

3. 生徒の運動に「不注意な」技術的誤りがみられる 場合には，手短かに誤りを修正して，運動に対す る集中力と努力を促すこと

4. 生徒に運動学的な知識の欠如や技術的誤りがみら れた場合には，具体的な運動技術に焦点づけて矯 正的フィードバックを与え, 継続的に努力寸るよ うに支援する。もし必要であれば、時間をかけて 繰り返し指導したり，練習内容を変更したりする こと

(Siedentop and Tunnehill, 2000, p. 270)

習にどのような影響がみられたかという両者の視 点から検討されるべきである。このことから，今 後のフィードバック研究では, 教師のフィードバ ックと子どもの受けとめかたとの対応関係を検討 していく必要がある，また，具体的な研究成果と しては，次の諸点が明らかにされた。

(1)子どもの傍で繰り返しフィードバックを与 え，わずかでも子どもに運動技能の改善や向上が みられれば賞賛を与えること。

(2)ある1つの重要な動作の局面に焦点づけてフ イードバックを与えること。

(3)子どもの不適切な動作を指摘したり，それを 修正させるための具体的なフィードバックを与え ること.

(4)子どもが運動体験から直接受け取ることがで きない情報のフィードバックを与えること．

(5)子どもに対して動作の過程を容易にイメージ させるような非言語的フィードバックと組み合わ せて与えること.

(6)注意散漫で失敗を繰り返す子どもには否定的 フィードバックを与え，学習に集中させること.

(7)目指すべき運動の達成基準に基づいて賞賛を 与えること.

(8)初心者や運動技能の低い子どもには単純で一 般的なフィードバックを与え，運動技能の高い子 どもには正確で具体的なフィードバックを与える
こと.

(9)フィードバックを与えた後, 子どもの運動学 習量を十分に保障すること，さらに，そこで子ど もが質の高い練習に対して，高い成功率で何度も 取り組んでいるかどうかを適切に評価するフィー ドバックを与えること。

くわえて，教師がこれらの効果的フィードバッ クを与えるためには，子どものつまずきを見抜き， 適切に対処する上で必要な指導経験や運動技術に 関する知識を習得しておく必要があることが示唆 された。

しかし一方では, 教師のフィードバックが子ど ものつまずきの改善や運動技能の向上につながら ず，必ずしも必要とされない場合が確認された。 たとえば，

a）子どもが運動から直接受け取ることができ る情報や内容のフィードバックを与えられ，次に どうすればよいかを具体的にイメージすることが できた場合，

b）教師が子どものつまずきを見䛊ったり，つ まずきの改善や運動技能の向上につながらない不 適切なフィードバック情報を与えた場合,

c）教師のフィードバックを受け取った後，子 どもに十分な練習時間が保障されない場合，

d）教師に与えられたフィードバックに基づい て，子どもが練習に取り組んだとしても，子ども の練習のしかたが不適切な場合などである.

このようにフィードバックの質的側面や，子ど もの学習状況及び受けとめかたをふまえれば，教 師のフィードバックが必ずしも有効に作用しない 場合も認められた。これら以外にも，フィードバ ックの頻度については，言語内容や対象となった 子どもの学習状況によって必ずしも数多く与える ことが望ましいとはいえず，状況に応じて適切な 頻度があることが示唆された。このような問題の 克服に向けて，最近では表5に示したように子ど もの学習反応に対応した教師のフィードバックの あり方 (Siedentop and Tunnehill, 2000, p. 270) が提案されている。これからのフィードバック研 究では，教師のフィードバックが子どものつまず きの改善，さらには運動技能の向上につながる適 
切な内容・頻度・与え方であるかといったフィー ドバックの「適切さ」を質的に検討していく必要 がある。

以上の結果をふまえて, 今後, 子どもの学習行 動に対応してフィードバックの有效性を検討しよ うとすれば，次のような方法が考えられる。た えば，1）子どもがどのような運動課題に取り組 み(課題の適切さ)，2）どのような学習状況がみ られたときに（運動につまずいている，成功して いる，子ども同士が話し合いをしているなど），3） 教師はどのような言語内容のフィードバック情報 を与えたのか，さらには4）その結果，子どもの 運動学習にはどのような変化がみられたか，など といったように状況関連的に教師のフィードバッ クの有效性を検討することが重要である．また一 方では，一連の教師のフィードバックをどのよう に受けとめたか，子どもに直接評価させることに よりフィードバックの有効性を正しく評価する必 要があると考えられる。

注

注 1）すべての著者は，これ以外にも体育授業に関す る様々な研究論文を著して扔り, 体育授業研究 の分野では国際的に著名な研究者である。たと えば, Siedentop, Silverman, Ennisらは, AAHPERD（アメリカ健康・体育・レクリエー ション・ダンス協会）の特別顧問，Rinkは NASPE（全米スポーツ・体育協会）の議長をそ れぞれ務めている。また，EnnisはJTPE誌と Quest誌の編集委員, RinkはJTPE 誌の編集委 員をしている。これらの学術研究誌は, 教師の 効果的フィードバックに関する研究論文が多数 投稿されて打り，世界の体育授業研究者によっ て高く評価されている。これら 4 名の研究者は, 同じ研究グループに属しており，その中心人物 がSiedentopである。彼は，1980年代に組織的 観察法を開発し，教師行動に関する多くの研究 論文を輩出している。また，スポーツ教育を提 唱するなどアメリカのスポーツ教育学分野にお けるオーソリティーといえる (Silverman and Ennis, 1996, pp. v-ix)。一方, Grahamは 1996 年にNASPEのカリキュラム・指導アカデミー部
門で名誉賞を受賞している（Graham，2001， p. 213). Mawerは, 現在イギリス体育協会の特 別顧問をしており，体育のプレサービス教師の アドバイザーでもある（Hardy and Mawer, 1999，p. 232).このような研究者たちに著され た 5 冊の文献は, 実際にアメリカのスポーツ教授 学を専攻する大学院生向けのテキストとして, さらには現職体育教師の教授技能改善に向けた テキストとして採用されている，以上のことか ら，これらの文献は，近年に扔ける教師の効果 的フィードバックに関する主要な研究並びに研 究成果が盛り込まれていると考え，それにかか わって有効な研究資料が得られると判断した。

注2）研究方法及び研究内容の分析視点は, Silverman and Skonie（1997，p. 303）が示したコーデ イングカテゴリーより，一部抜粋して著者が作 成した。彼らは，研究方法を「質的」「量的」 「两方（質的＋量的）」の3つに区分しているが， 本研究では教師の効果的フィードバックに関す る幅広い研究成果を収集するために「研究者の 考えや意見」を含めて，表2で示したように全 4 カテゴリーで検討した。また，研究内容につい ては本研究での分析視点と正しく対応していな かったため，すべての分析視点を網羅するよう な項目を設定して分析した.

注 3）大友ほか（2002，pp. 97-99）の論文に示され た表1-2-1-3には「授業観察の実施」「視聴覚 機器に授業の記録の有無」の 2 つが存在するが, 表1ではそれらの記述内容を意図的に除外した。 それは，これらの 2 項目が質的研究の特徵という よりも, むしろ量的研究の研究方法の一般的特 徵と考えられるからである。

注4）場所と時間を設定して行うインタビュー法であ る。一般的に，この方法を用いた研究ではイン 夕ビューの様子が録音・録画され，その内容が データとして書き起こされる（大友ほか，2002， p. 107).フォーマルインタビューの中でも，こ こでは「刺激再生インタビュー（= StimulatedRecall Interviews)」が用いられた. 刺激再生イ ンタビューとは，授業中の教師行動を録画した VTRを授業後に再生し，その中で生じた特定の 行動を振り返らせて，その場面における教師の 認識を明らかにする方法である（Bonnie，1997， p. 391). 
注5）メラビアンによれば，会話表現における全メッ セージのうち $7 \%$ が言語, $38 \%$ が音声の特徵, $55 \%$ 顔の表情によるという。この割合から， メッセージの $93 \%$ は非言語であり，コミュニヶ ーションにおける非言語メッセージの役割は大 変重要であるといえる(御手洗，2000，p.6）。

注6）学習キュー（learning cue）とは，子どもがあ る運動に取り組む際に，事前に伝えられる重要 な動作，技術，課題に関する特徴（Mawer, 1995，p. 171）である.

注 7）ここでいう否定的フィードバックとは，たとえ ば「スージー，ドリブルのとき指先を使ってる よ．手のひら全体を使ってね」といったように 子どもの不適切な動作を否定するもので，子ど ものつまずきの改善に役に立つ内容である (Graham, 2001, p. 141). 最近の研究では, 具 体的な批評 (specific criticism) は, 矯正的フィ ードバックとしてみなされている（Rink，1998， p. 56）ように，高橋 (1991，p. $195 ； 1994$, pp. 242-243）が用いている「否定的フィードバ ック」の柣念とは若干捉え方が異なると考えら れる。これについては，両者の捉え方のズレを 明確にして，概念規定を再検討する必要がある。

注 8）他方で，子どもに技能成果（student achievement）がみられたときに，それが教師のフィー ドバックによるものなのか，あるいは単に数多 く練習に取り組んだことによるものなのか,ど ちらかに判断することが難しいといった問題が 指摘されている，そこで，近年では練習回数を 統制する試みも行われている (Silverman et al., 1992, pp. 337-338).

\section{文献}

Bogdan, T. and Bikken, S. (1992) Qualitative research for education 2nd ed. Allyn and Bacon: Boston.

Bonnie, T. (1997) A comparison of teacher and student perspective of tasks and feedback. Journal of teaching in physical education, 16: 388-400.

Carlisle, C. and Phillips, A. (1984) The effect of enthusiasm training on selected teacher and student behaviours in pre-service physical education teachers. Journal of teaching in physical education, 4: 64-75.

深見英一郎・高橋健夫 ·日野克博 - 吉野 聡 (1997)
体育授業における有効なフィードバック行動に関 する検討：特に，子どもの受けとめかたや授業評 価との関係を中心に。体育学研究, 42：167-179.

Graham, G. (2001) Teaching children physical education: Becoming a master teacher 2nd ed. Human Kinetics: U.S.A.

Hardy, C. and Mawer, M. (1999) Learning and teaching in physical education. Falmer Press: London, p. 232.

Lee, A., Keh, N., and Magill, A. (1993) Instructional effects of teacher feedback in physical education. Journal of teaching in physical education, 12: 228243.

Magill, A. (1993) Augmented feedback in skill acquisition. In: Singer, R.N., Murphey, M., and Tennant, K.L. (Eds.) Handbook of research on sports psychology. Macmillan: New York, pp. 193-212.

Magill, A. (1994) The influence of augmented feedback during skill learning depends on characteristics of the skill and the learner. Quest, 46: 314-327.

Magill, A. and Wood, A. (1986) Knowledge of results as a learned variable in motor skill acquisition. Research quarterly for exercise and sport, 57: 170173.

Mawer. M. (1995) The effective teaching of physical education. Addison Wesley Longman: New York.

Metzler, M. (2000) Instructional models for physical education. Allyn \& Bacon: U.S.A., pp. 102-106.

文部科学省 (2001) 平成 14 年度 文部科学白書「新 しい時代の学校一進む初等中等教育改革一.

御手洗昭治（2000）異文化にみる非言語コミュニケ ーションーVサインは屈辱のサイン?一、ゅまに 書房：東京, p. 6 .

大友 智. 吉野 聡 - 高橋健夫 - 岡出美則 - 深見英 一郎・細越淳二（2002）米国における質的体育授 業研究の「目的」及び「方法」の特徵一JTPE誌の 研究例の分析から一. スポーツ教育学研究, 22 : 93-113.

Pieron, M. (1982) Effectiveness of teaching a psychomotor task: Study in a micro-teaching setting. In: Pieron, M. and Cheffers. J. (Eds.) Studying the teaching physical education. University of Liege, Belgium, AlESEP. pp. 78-89.

Rikard, L. (1991) The short-term relationship of 
teacher feedback and student practice. Journal of teaching in physical education, 10: 275-285.

Rikard, L. (1992) The relationship of teachers' task refinement and feedback to students' practice success. Journal of teaching in physical education, 10: 349-357.

Rink, J. (1993) Teaching physical education for learning. St. Louis: Mosby.

Sharpe, T. (1993) What are some guidelines on giving feedback to students in physical education? Journal of physical education, recreation and dance, 64 : 13.

シーデントップ：高橋健夫ほか訳（1988）体育の教 授技術. 大修館書店：東京. 〈Siedentop, D. (1983) Developing teaching skills in physical education. 2nd Ed, Mayfield Pub. Co: California.)

Siedentop, D. and Tunnehill, D. (2000) Developing teaching skills in physical education. 4th Ed, Mayfield Pub. Co: California.

Silverman, S. and Ennis, C. (1996) Student learning in physical education. Human Kinetics: U.S.A.

Silverman, S. and Skonie, R. (1997) Research on teaching in physical education: An analysis of published research. Journal of teaching in physical education, 16: 300-311.

Silverman, S., Tyson, L., and Krampitz, J. (1992) Teacher feedback and achievement in physical education. Teaching and teacher education, 8: 333334.

Silverman, S., Tyson, L., and Krampitz, J. (1993) Teacher feedback and achievement: Mediating effects of initial skill and sex. Journal of human movement studies, 24: 97-118.

Steven, T. (1996) Differences between experienced and inexperienced physical education teachers' augmented feedback and interactive teaching decisions. Journal of teaching in physical education, 15: $151-170$.

Stroot, S. and Oslin, J. (1993) Use of instructional statement by preservice teachers for overhand throwing performance of children. Journal of teaching in physical education, 13: 24-45.

高橋健夫（1989）新しい体育の授業研究. 大修館書 店: 東京, pp. 177-181.

高橋健夫（1994）体育の授業を創る。大修館書店： 東京.

高橋健夫・岡沢祥訓 - 中井隆司 - 吉本 真 (1991)

体育授業における教師行動に関する研究一教師行 動の構造と児童の授業評価との関係一. 体育学研 究, $36: 193-208$.

高橋健夫・鈴木 理（1994）体育授業における教師 行動分析の研究動向一特に相互作用の言語的・非 言語的行動を中心に一。体育の科学, $44 ： 217$ 222.

高橋健夫 - 歌川好夫 - 吉野 聡 - 日野克博 - 深見英 一郎・清水茂幸（1996）教師の相互作用及びその 表現のしかたが子どもの形成的授業評価に及ぼす 影響。スポーツ教育学研究，16：13-23.

Van der Mars, H. (1989) Effects of specific verbal praise on off-task behavior of second grade students in physical education. Journal of teaching in physical education, 8: 162-169.

渡辺 伸 (1996) 運動学習の創造性を考える. 金子 明友監修 吉田 茂・三木四郎編 教師のための 運動学. 大修館書店：東京, pp. 48-57.

Werner P. and Rink, J. (1989) Case studies of teacher effectiveness in physical education. Journal of teaching in physical education, 4: 280-297.

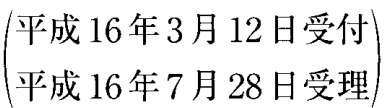

